\title{
Efektivitas Teknik Relaksasi Progresif Terhadap Tingkat Kesulitan Tidur pada Lansia di Balai Sosial Lanjut Usia Meci Angi Kota Bima
}

\author{
Dahlan $^{1(\mathrm{CA})}$, Rini Hendari², Arismansyah ${ }^{3}$ \\ 1(CA)Jurusan Keperawatan, Poltekkes Kemenkes Mataram, Indonesia; dahlandahmad13@gmail.com \\ (Corresponding Author) \\ 2,3 Jurusan Keperawatan, Poltekkes Kemenkes Mataram, Indonesia
}

\begin{abstract}
Background : Relaxation is a technique that develops physiological methods to fight tension, which is a technique to reduce muscle tension based on muscle contraction. Pharmacological therapy by giving sleeping pills to the elderly is not the only best way that can be done to the elderly who have difficulty sleeping. One of the efforts of non-pharmacological therapy to overcome sleep difficulties in the elderly is the relaxation method. Objective : To determine the effectiveness of Progressive Relaxation Techniques Against the Level of Sleep Difficulties in the Elderly at Meci Angi Elderly Social Center, Bima City. Method : The design used in this study was pre-experimental using the One Group Pretest Posttest design approach. How to take samples using purposive sampling. The research instrument used was a questioner. Data were analyzed using paired T-test with a significant level $(\rho<0.05)$. Results : The study showed that there was a significant change in value after the administration of progressive relaxation techniques. With a significant value of $\rho=0,000$. Then $\mathrm{H} 0$ is rejected and $\mathrm{H} 1$ is accepted which means there is the Effectiveness of Progressive Relaxation Techniques Against the Level of Sleep Difficulties in the Elderly at Meci Angi Elderly Social Center in Bima City. Conclusion : Based on the results of the study, the health workers at BSLU Meci Angi City of Bima can do non-pharmacological treatment in the form of progressive relaxation techniques to help overcome sleep difficulties in the elderly.
\end{abstract}

Keywords: Progressive relaxation techniques; difficulty sleeping; elderly

\begin{abstract}
ABSTRAK
Latar Belakang : Relaksasi adalah satu teknik yang mengembangkan metode fisiologis melawan ketegangan yaitu teknik untuk mengurangi ketegangan otot didasarkan pada kontraksi otot. Salah satu upaya terapi non farmakologi mengatasi kesulitan tidur pada lansia adalah dengan metode relaksasi. Tujuan : Untuk mengetahui Efektifitas Teknik Relaksasi Progresif Terhadap Tingkat Kesulitan Tidur Pada Lansia Di Balai Sosial Lanjut Usia Meci Angi Kota Bima. Metode : Desain yang digunakan dalam penelitian ini adalah pra eksperimen dengan menggunakan pendekatan One Group Pretest - Posttest design. Cara pengambilan sampel menggunakan purposive sampling. Instrument penelitian yang digunakan questioner. Data di analisis menggunakan uji paired T-test dengan tingkat signifikan $(\rho<$ 0,05). Hasil : Penelitian menunjukan ada perubahan yang signifikan setelah diberikannya teknik relaksasi progresif.dengan nilai signifikan $\rho=0,000$. Maka H0 ditolak artinya ada Efektifitas Teknik Relaksasi Progresif Terhadap Tingkat Kesulitan Tidur Pada Lansia Di Balai Sosial Lanjut Usia Meci Angi Kota Bima. Kesimpulan : Petugas kesehatan di BSLU Meci Angi Kota Bima bisa melakukan pengobatan non farmakologi berupa teknik relaksasi progresif untuk membantu mengatasi kesulitan tidur pada lansia.
\end{abstract}

Kata kunci: Teknik relaksasi progresif; kesulitan tidur; lansia. 


\section{PENDAHULUAN}

Teknik relaksasi otot progresif merupakan salah satu terapi untuk mengatasi kecemasan, dimana terapi ini dilakukan dengan cara menegangkan otot dan kemudian dirilekskan. Terapi ini sangat sederhana, tidak memerlukan permainan pikiran atau imajinasi, tekad atau mensugesti seseorang, tetapi dilakukan secara personal (Gemilang, 2013). Kaitan antara tehnik relaksasi dengan gangguan tidur sangat erat atau mempunyai berhubungan karena istirahat dan tidur tergantung tekhnik relaksasi otot (Hirnle, 2000). Penuaan dapat menimbulkan berbagai masalah fisik, biologik, mental maupun sosial ekonomis. Gangguan penyakit atau keluhan yang umum diderita adalah hipertensi, penyakit jantung, penyakit paru, jatuh, parali-sis, osteoporosis, gangguan patah tulang dan gangguan tidur atau istrahat (Maryam, 2008).

kesulitan tidur yang terjadi pada sebagian besar orang merupakan kejadian dimana individu mengalami perubahan yaitu dalam jumlah dan kualitas pola istirahat atau tidur sehingga menyebabkan ketidaknyamanan atau terkena penyakit tertentu. Kesulitan tidur yang dialami lansia menyebabkan beberapa gangguan terjadi seperti perasaan lelah, gelisah, lesu dan apatis, kehitaman didaerah sekitar mata, kelopak mata bengkak, konjungtiva merah, mata perih, perhatian terpecah-pecah, sakit kepala, dan sering menguap atau mengantuk (Alimul 2006).

Gangguan kurang tidur pada lansia dapat membahayakan terutama pada lansia karena mereka lebih rentan terhadap gangguan penyakit tertentu yang disebabkan gangguan tidur atau istrahat. Akibat yang muncul Bila tidur kurang lelap adalah merasa letih, lemah, dan lesu dan tidak bersemangat pada saat bangun untuk beraktifitas. Kehilangan jam tidur mempunyai akibat yang sangat besar bagi semangat, kemampuan konsentrasi, kinerja, produktivitas, ketrampilan komunikasi, dan kesehatan secara umum, termasuk sistem gastrointestinal, fungsi kardiofaskuler dan sistem kekebalan tubuh (Parmet, 2003).

Jumlah penderita insomnia di Indonesia terutama pada lansia tergolong tinggi yaitu sekitar $67 \%$ dari populasi yang berusia diatas 65 tahun. Hasil penelusuran penelitian didapatkan sebagian besar insomnia dialami oleh perempuan yaitu sebesar 78,1\% dengan usia 60-74 tahun (Sulistyarini \& Santosa, 2016). Berdasarkan data yang di dapatkan dari Balai Sosial Lanjut Usia Meci Angi Kota Bima terdapat 53 orang lansia yang menetap disana dengan jumlah lansia laki-laki sebanyak 26 orang dan lansia perempuan sebanyak 27 orang, dari sejumlah lansia 53 orang berdasarkan wawancara awal yang dilakukan saat praktek keperawatan gerontik di BSLU Meci Angi Kota Bima pada tahun 2018 tercatat 20 orang lansia mengeluh mengalami kesulitan tidur sehingga terkadang membuat mereka lemas ketika di pagi harinya .

Terapi farmakologi dengan memberikan obat tidur kepada lansia bukanlah satu-satunya cara terbaik yang bisa di lakukan kepada lansia yang mengalami kesulitan tidur karena di lihat lagi dengan keadaan lansia yang biasanya rentan apabila terpapar obat - obatan terus menerus akan memperburuk keadaan ginjal pada lansia tersebut. Salah satu upaya terapi non farmakologi untuk mengatasi gangguan kesulitan tidur pada lansia adalah dengan menggunakan metode relaksasi. Tekhnk relaksasi merupakan teknik yang mengembangkan metode fisik untuk mengurangi tekanan atau ketegangan otot atau fikiran karena kontraksi otot atau stress. Berdasarkan masalah yang telah dipaparkan di atas maka peneliti 
tertarik untuk melakukan penelitian tentang "Efektivitas Teknik Relaksasi Progresif Terhadap Tingkat kesulitan Tidur Pada Lansia Di Balai Sosial Lanjut Usia Meci Angi Kota Bima “

\section{METODE}

Penelitian ini menggunakan desain penelitian pra eksperimen dengan pendekatan One Group Pretest - Posttest design yaitu suatu penelitian yang dilakukan dengan satu kelompok yang diberi perlakuan tertentu, kemudian diobservasi sebelum dan sesudah perlakuan. Metode ini untuk membandingkan perubahan setelah diberikan perlakuan pada kelompok yang sudah ditentukan. Bentuk rancangan desain penelitian Pra Eksperimen dengan One Group Pretest - Posttest design (Sudibyo supardi dan Rustika, $2013: 58)$.

Perlakuan yang diberikan terhadap lansia dengan keluhan kesulitan tidur adalah dengan memberikan terapi relaksasi progresif selama 20-30 menit untuk satu kali latihan selama 7 hari. Perlakuan terapi progresif dilakukan setelah di nilai dahulu tingkat kesulitan tidur lansia yang mengeluhkan kurang tidur sebelum dilakukan teknik relaksasi progresif, setelah itu dilakukan teknik relaksasi progresif dan setelah beberapa hari di lakukan penilaian kembali atau post test pada tingkat kesulitan tidur pada lansia. Hasil analisis menggunakan uji statistik Paired T Test dengan tingkat Kemaknaan $\mathrm{P} \leq 0,05$.

\section{HASIL}

Tabel 1. Karakteristik responden

\begin{tabular}{llcc}
\hline No & Karakteristik responden & Jumlah $(\mathrm{n}=40)$ & Persentase $(\%)$ \\
\hline 1 & Jenis kelamin & 10 & \\
& Laki-laki & 10 & 50,0 \\
& Perempuan & & 50,0 \\
2 & Umur & 13 & \\
& $60-75$ tahun & 7 & 85,0 \\
& $76-90$ tahun & & 15,0 \\
\hline
\end{tabular}

Tabel 1 menunjukan distribusi responden berdasar jenis kelamin sama sama berjumlah 10 orang, sementara karakteristik responden berdasar usia sebagian besar pada rentang 60 - 74 Tahun.

Tabel 2. Distribusi frekuensi Tingkat kesulitan tidur sebelum dan sesudah perlakuan teknik relaksasi progresif Pada lansia di Balai Sosial Lanjut Usia Meci Angi Kota Bima

\begin{tabular}{clcc}
\hline No & Tingkat kesulitan tidur & Jumlah $(\mathrm{n}=40)$ & Persentase $(\%)$ \\
\hline 1 & Sebelum perlakuan & 0 & \\
& Tidak insomnia & 18 & 0,0 \\
& Insomnia ringan & 2 & 90,0 \\
& Insomnia berat & 0 & 10,0 \\
& Insomnia Sangat Berat & 0,0 \\
\hline
\end{tabular}




\begin{tabular}{clcc}
\hline No & Tingkat kesulitan tidur & Jumlah $(\mathrm{n}=40)$ & Persentase (\%) \\
\hline 2 & Setelah perlakuan & & \\
& Tidak insomnia & 14 & 70,0 \\
& Insomnia ringan & 6 & 30,0 \\
& Insomnia berat & 0 & 0,0 \\
& Insomnia Sangat Berat & 0 & 0,0 \\
\hline
\end{tabular}

Berdasar tabel 2 diatas, tingkat kesulitan tidur sebelum perlakuan teknik relaksasi progresif erbanyak adalah tingkat ringan dengan, sedangkan sesudah perlakuan teknik relaksasi progresif tingkat kesulitan tidur terbanyak adalah tingkat tidak insomnia.

Tabel 3. Perubahan tingkat kesulitan tidur sebelum dan sesudah perlakuan teknik relaksasi progresif pada lansia di Balai Sosial Lanjut Usia Meci Angi Kota Bima

\begin{tabular}{lccc}
\hline \multirow{2}{*}{ Tingkat kesulitan tidur } & \multicolumn{2}{c}{ teknik relaksasi progresif } & \multirow{2}{*}{-value } \\
\cline { 2 - 3 } & Sebelum perlakuan & Sesudah perlakuan & \\
\hline Tidak insomnia & 0 & 14 & \\
Insomnia ringan & 18 & 6 & 0,000 \\
Insomnia berat & 2 & 0 & \\
Insomnia Sangat Berat & 0 & 0 & \\
\hline
\end{tabular}

Menunjukan bahwa rata-rata hasil pengukuran tingkat kesulitan tidur sebelum perlakuan teknik relaksasi progresif yaitu berada pada tingkat ringan sejumlah 18 responden dan sesudah perlakuan teknik relaksasi progresif menurun rata - rata yaitu berada pada tingkat tidak insomnia sejumlah 14 responden. Berdasarkan table diatas menunjukan bahwa hasil perubahan tingkat kesulitan tidur responden sesudah perlakuan teknik relaksasi progresif sebagian besar mengalami penurunan tingkat kesulitan tidur sebanyak 16 responden $(80,0 \%)$ dan yang tidak mengalami penurunan tingkat kesulitan tidur sebanyak 4 responden $(20,0 \%)$. Hasil analisis uji statistik menggunakan rumus uji Paired T Test diperoleh hasil nilai $\rho=0,000$ untuk perlakuan teknik relaksasi progresif $(\rho<0,05)$ dengan demikian secara statistik pada tingkat kepercayaan $95 \%$ ada perubahan nilai signifikan setelah diberikannya perlakuan teknik relaksasi progresif.

\section{PEMBAHASAN}

Berdasarkan hasil penelitian dapat disimpulkan bahwa tingkat kesulitan tidur sebelum perlakuan teknik relaksasi progresif dengan jumlah responden 20 orang dimana tingkat kesulitan tidur terbanyak adalah tingkat ringan dengan jumlah 18 responden, dan 2 responden berada pada posisi tingkat kesulitan tidur berat . dimana berdasarkan pernyataan dari 18 responden yang mengalami insomnia ringan mengatakan bahwa faktor yang menyebabkan mereka sulit tidur karena faktor lingkungannya yang pengap dan panas sehingga sulit tidur, selain itu juga disebabkan oleh faktor umur membuat mereka sering terbangun untuk BAK di tengah malam dan sulit untuk tidur kembali setelahnya. 
Kesulitan tidur / insomnia ringan merupakan kondisi yang dikeluhkan dengan tanda-tanda seperti kesulitan tidur, tidur tidak tenang, resah, kaget saat tidur, kesulitan menahan tidur, sering terbangun dipertengahan malam, dan seringnya terbangun diawal. Insomnia mempunyai sifat berulang dan berlangsung beberapa hari saja sampai dua atau tiga minggg tetapi pada kasus yang kronis insomnia bisa bertahan lebih lama lagi. Lansia sering mengeluhkan kejadian tersebut terutama yang ada di Balai Sosial Lanjut Usia Meci Angi Kota Bima mereka mengatakan bahwa kerap kali merasa lemas karena dimalam harinya mengalami kesulitan tidur. Penanganan yang cepat perlu dilakukan mengingat dampak yang ditimbulkan baik jangka pendek maupun jangka panjang akan mengakibatkan perubahan-perubahan pada siklus tidur, biologiknya atau menurun daya tahan tubuh pada lansia serta menurunkan prestasi kerja, mudah tersinggung, depresi,kurang konsentrasi, kelelahan, yang pada akhirnya dapat mempengaruhi keselamatan diri sendiri atau orang lain (Rafknowledge, 2004: 57).

Faktor-faktor yang mempengaruhi kesulitan tidur pada lansia di BSLU Meci Angi Kota Bima antara lain di sebabkan oleh faktor lingkungan seperti keadaan ruangan kamar yang panas atau pengap di keluhkan oleh beberapa lansia di sana membuat mereka merasa tidak nyaman karena kepanasan, serta pengap karena tempat sirkulasi udara yang kurang dan kurang terpapar sinar matahari,selain itu dari faktor pencahayaan kamar yang terlalu terang membuat mereka sulit tidur. Faktor-faktor yang menyebabkan kesulitan istirahat tidur yaitu lingkungan yang buruk, lingkungan dengan kurangnya variasi tempat tinggal dapat membuat kejenuhan dan mempengaruhi kualitas tidur, kelainan kejiwaan seperti: stres, depresi dan anastesi, peroses penyakit, kelelahan, alkohol, Makanan dan minuman, gangguan fisik, masalah medis dan obat-obatan (Wicaksono. 2012).

Gangguan atau kesulitan tiduryang disebut insomnia ringan disebabkan karena stress, bising, perbedaan suhu udara (PH), perubahan lingkungan sekitar, masalah jadwal tidur dan bangun yang tidak teratur, efek samping pengobatan. Menurut (Kartono, 2000 ; Rafknowladge, 2004). Seperti yang kita ketahui sebelumnya masa lansia merupakan masa dimana pada individu yang memasuki masa lansia akan mengalami penurunan fungsi dari tiap organ tubuh sehingga rentan terkena penyakit, selain itu kesulitan tidur pada lansia juga berdampak pada kondisi kesehatan lansia tersebut karena perubahan pada siklus tidur biologiknya dapat menyebabkan penurunan daya tahan tunuh pada lansia itu sendiri. Maka dari itu pengobatan non farmakologi sangat diperlukan untuk membantu mengurangi tingkat kesulitan tidur pada lansia.

Dari hasil penelitian ini di dapatkan dari 20 responden menunjukan bahwa responden yang mengalami kesulitan tidur sebagian besar memiliki usia pada rentang 60 - 74 Tahun yaitu dengan jumlah 17 responden $(85,0 \%)$ dan 70 - 90 tahun dengan jumlah 3 responden (15,0 5). Berdasarkan hasil penelitian dapat disimpulkan bahwa tingkat kesulitan tidur sesudah perlakuan teknik relaksasi progresif dengan jumlah responden 20 orang dimana tingkat kesulitan tidur terbanyak berada pada tingkat tidak insomnia dengan jumlah 14 responden, dan tingkat ringan 6 responden.

Data tersebut menunjukan rata-rata tingkat kesulitan tidur pada lansia di Balai Sosial Lanjut Usia Meci Angi Kota Bima mengalami penurunan dibandingkan sebelum perlakuan teknik relaksasi progresif. Dimana baik di berikan perlakuan tindakan relaksasi progresif lansia juga di berikan arahan untuk mengatur jam tidurnya dengan teratur sehingga tidak mengalami kesulitan tidur lagi. Penurunan tingkat 
kesulitan tidur yang dimaksud adalah ketika lansia yang sebelumya mengalami kesulitan tidur setelah dilakukannya teknik relaksasi progresif selama 7 hari mengatakan bahwa kesulitan tidur yang di alami sudah berkurang daripada sebelumnya. Faktor-faktor yang menyebabkan kesulitan istirahat tidur yaitu: Lingkungan yang buruk, lingkungan dengan kurangnya variasi tempat tinggal dapat membuat kejenuhan dan mempengaruhi kualitas tidur, kelainan kejiwaan seperti: stres, depresi dan anastesi, peroses penyakit, kelelahan, alkohol, Makanan dan minuman, gangguan fisik, masalah medis dan obat - obatan (Wicaksono, 2012).

Tujuan relaksasi untuk menahan terbentuknya respon stres terutama dalam system syaraf dan hormon. Teknik relaksasi dapat mengembalikan tubuh ke kondisi yang tenang dan damai. Teknik relaksasi selain menyebabkan efek yang menenangkan fisik juga dapat menenangkan pikiran. Teknik relaksasi dapat membuat tidur menjadi lebih baik. Relaksasi terdiri dari imajinasi mental, pelatihan otogenik, terapi musik, latihan fisik, pernapasan diafragma, relaksasi progresif, serta meditasi (Davis, 1987).

Hal ini sejalan dengan penelitian yang dilakukan sebelumnya oleh Wahyuningsih Safitri dan Wahyu Rima Terhadap Penurunan Tingkat Insomnia Pada Lansia Di Panti Wreda Dharma Bakti Kasih Agustin pada tahun 2015 dengan judul penelitian “ Pengaruh Terapi Relaksasi Progresif Surakarta “. Dengan hasil penelitian menunjukkan ada pengaruh terapi relaksasi progresif terhadap penurunan tingkat insomnia pada lansia di Panti Wreda Bakti Kasih Surakarta.

Sehingga peneliti dapat menyimpulkan bahwa sesudah perlakuan teknik relaksasi progresif selama tujuh hari, tingkat kesulitan tidur responden menurun dari pada sebelum perlakuan teknik relaksasi progresif, dimana responden menyatakan bahwa masalah kesulitan tidurnya sudah berkurang dari pada sebelumnya. Penurunan tingkat kesulitan tidur yang terjadi dipengaruhi karena teknik relaksasi progresif dapat mengembalikan tubuh ke kondisi yang tenang dan rileks sehingga dapat melakukan kegiatan dengan baik (Muhtar \& Aniharyati, 2019).

Berdasarkan hasil penelitian Menunjukan bahwa rata-rata hasil pengukuran tingkat kesulitan tidur sebelum perlakuan teknik relaksasi progresif yaitu berada pada tingkat ringan sejumlah 18 responden dan sesudah perlakuan teknik relaksasi progresif menurun rata - rata yaitu berada pada tingkat tidak insomnia sejumlah 14 responden. Dan hasil perubahan tingkat kesulitan tidur responden sesudah perlakuan teknik relaksasi progresif sebagian besar mengalami penurunan tingkat kesulitan tidur sebanyak 16 responden $(80,0 \%)$ dan yang tidak mengalami penurunan tingkat kesulitan tidur sebanyak 4 responden $(20,0 \%)$.

Hasil analisis uji statistik menggunakan rumus uji Paired T Test dengan bantuan program SPSS diperoleh hasil nilai $\rho=0,000$ untuk perlakuan teknik relaksasi progresif $(\rho<0,05)$ dengan demikian secara statistik pada tingkat kepercayaan $95 \%$ ada perubahan nilai signifikan setelah diberikannya perlakuan teknik relaksasi progresif. Terapi farmakologi dengan memberikan obat tidur kepada lansia bukanlah satu-satunya cara terbaik yang bisa di lakukan kepada lansia yang mengalami kesulitan tidur karena di lihat lagi dengan keadaan lansia yang biasanya rentan apabila terpapar obat - obatan terus menerus akan memperburuk keadaan ginjal pada lansia tersebut. Salah satu upaya terapi non farmakologi mengurangi efek negatif obat-obatan dan membuat tubuh lebih ringan dan rileks. Terapi juga harus 
dibarengi dengan pola hidup sehat seperti pola makan buah dan sayur serta aktifitas fisik lainya sesuai usia (Wicaksono, 2012; Rostinah. Nelly, 2021)

Peneliti dapat menyimpulkan bahwa perlakuan teknik relaksasi progresif yang dilakukan selama penelitian dapat menurunkan tingkat kesulitan tidur pada lansia karena teknik relaksasi progresif memberikan efek tenang yang membantu lansia yang mengalami kesulitan tidur agar bisa mengatasi kesulitan tidur atau gangguan tidur. Hal ini sesuai dengan penelitian yang dilakukan oleh Rina Maryana tahun 2018 dengan judul penelitian Efektivitas Teknik Relaksasi Progresif Dalam Mengurangi Kesulitan Tidur Pada Remaja yang dilakukan pada 20 orang responden yang terbagi menjadi 2 kelompok dimana 10 orang pada kelompok kontrol tanpa di beri perlakuan dan 10 orang pada kelompok dengan pemberian teknik relaksasi progresif, dimana didapatkan hasil bahwa pemberian teknik relaksasi progresif selama 20 menit dapat menurunkan kesulitan tidur yang di alami oleh remaja.

\section{KESIMPULAN}

Efektifitas perlakuan teknik relaksasi progresif terhadap lansia yang mengalami kesulitan tidur harus tetap dibarengi dengan pola hidup sehat, karena tanpa pola hidup yang sehat tidak akan mampu menerapkan efektifitas teknik relaksasi progresif terhadap tingkat kesulitan tidur pada lansia di Balai Sosial Lanjut Usia Meci Angi Kota Bima.

\section{DAFTAR PUSTAKA}

Alimul, A. Pengantar Kebutuhan Dasar Manusia. Aplikasi Konsep Dan Proses Keperawatan. Jakarta: Salemba Medika, 2006.

Asmadi. Tehnik Prosedural Keperawatan: Konsep Dan Aplikasi Kebutuhan Dasar Klien. Jakarta: Salemba Medika, 2008.

Bandiyah, S. 2009. Lanjut Usia dan Keperawatan Gerontik. Yogyakarta: Nuha Medika

Davis, Eshelman dkk. 1995. Panduan Relaksasi dan Reduksi Stres. Edisi III. Jakarta: EGC

Gemilang, J, (2013). Buku Pintar Manajemen stres dan Emosi. Yogyakarta: Mantra Books.

Hoesin, Haslizen. 2017. Alat Ukur Penelitian di https://lizenhs.wordpress.com/2017/06/08/alat-ukurpenelitian/

Iwan, Skala Insomnia (KSPBJ Insomnia Rating Scale), 2009.

Japardi,I (2002). Gangguan Tidur, Jurnal : Universitas Sumatra Utara.

Maryam, Siti dkk. 2008. Mengenal Usia Lanjut dan Perawatannya. Jakarta: Salemba Me- dika

Maryana Rina. 2018. Efektivitas Teknik Relaksasi Progresif Dalam Mengurangi Kesulitan Tidur Pada Remaja.

Muhtar, \& Aniharyati. (2019). Dukungan Pemenuhan Activity Daily Living (ADL) Pada Lanjut Usia di Balai Sosial Lanjut Usia Meci Angi. Bima Nursing Journal, 1(1), 64-69. https://doi.org/https://doi.org/10.32807/bnj.v1i1.533

Parmet. Sharon., lynm. Casio, Glass., Richard. 2003. Insomnia Journalof American Medical Association. 
Vol 289 No 19

Parás-Bravo, Paula et al. "The Impact of Muscle Relaxation Techniques on the Quality of Life of Cancer Patients, as Measured by the FACT-G Questionnaire.” PLoS ONE 12.10 (2017): 1-14. Web.

Padila. (2013). Buku Ajar Keperawatan Gerontik. Yogyakarta: Nuha Medika

Rafknowledge. 2004. Insomnia dan Gangguan Tidur Lainnya. Jakarta: PT Elex Media Komputindo

Rostinah, Nelly. 2020. Faktor-faktor yang Mempengaruhi Konsumsi Buah dan Sayur. Prosiding Forum Ilmiah Tahunan IAKMI (Ikatan Ahli Kesehatan Masyarakat Indonesia. 1-6.

Setyoadi, Kushariyadi, (2011). Terapi Modalitas Keperawatan Jiwa pada Klien Psikogeriatrik. Jakarta : Salemba Medika.

Tasya. 2011. Istirahat dan Tidur, (online), (http://iftasya.wordpress.com /2011/01/11/pemenuhankebutuhan-istirahat-dan-tidur/)

Utami. 2002. Prosedur Relaksasi. Yogyakarta: Fakultas Psikologi UGM.

Wicaksono, D.W. (2012). Analisis Faktor Domain yang Berhubungan dengan Kualitas Tidur Pada Mahasiswa Fakultas Keperawatan Universitas Airlangga Surabaya. 